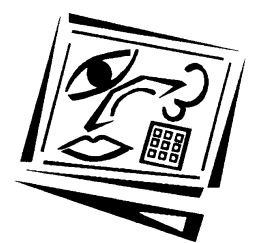

\title{
Critical discourse analysis of collaborative engagement in Facebook postings
}

\author{
Patient Rambe \\ University of the Free State, South Africa
}

\begin{abstract}
While research literature affirms the potential for social networking sites (SNSs) to democratise communication, their impact on micro-level, academic relations at university level has not been explored sufficiently in developing countries. The literature on SNSs (especially Facebook) has emphasised its appropriation for the marketing of university programs to prospective students and enhancing institutionallevel contact between university administration and students. As such, the impact of SNSs on micro-level (educator-learner and learner-peer) relations and relational power remains speculative. Mindful of how discursive types and discourses inform the construction of social power, this study employs critical discourse analysis (CDA) and educator-learners Facebook conversations to expose the exercise of relational power and social learning in these interactional spaces. Facebook postings are examined to explore academic relations and associated learner challenges like limited meaningful engagement with peers and content, superficial learning and general academic underpreparedness. The findings suggest the prevalence of formal authoritative (or hierarchical) discourses, few informal liberating (horizontal) discourses, nascent peerbased collaboration and limited learner engagement with theory. These phenomena generally point at first year students' under-developed study skills and less sophisticated literacies. The challenges and potential for transformative learning are explored and possibilities for effective engagement suggested.
\end{abstract}

\section{Introduction}

Facebook is among the most trafficked social networking sites (SNSs) on the Internet. As of June 2011, Facebook is the top ranked SNS in the world (with 550 million users) (Facebook, 2011). As at 24 November 2011, World Wide Worx research estimated that there were approximately 4.2 million Facebook users and 1.1 million Twitter users in South Africa (cited in Sousa, 2011). Moore (2010) claimed that in South Africa, a youth culture is visible on Facebook with almost a million (42\% of South African Facebook users) aged 14-24 using the site (Moore, 2010) for the exchange of resources and informal learning. Given that many university students fall within this age group, it is expected that many of them have seamlessly integrated Facebook into their lives. Mindful of the $98 \%$ ownership of cell (mobile) phones at some South African universities (Centre for Educational Technology, 2010) combined with student access to social applications via their phones, it is envisaged that Facebook presents diverse academic opportunities. Despite this uptake of Facebook in academia, there is still a limited grasp of the discourses that unfold on this SNS. This is notwithstanding the predominantly text-based nature of Facebook discourses and university students' universal access to the Internet at South African universities. 
Despite the rising interest in the academic application of Facebook (Kolek \& Saunders, 2008; Guess, 2008; Shim, 2008), there is a paucity of studies using critical discourse analysis (CDA) as an interpretive or analytical framework for exploring SNSs. Fairclough (1995) defines CDA as the study of opaque relationships of causality and determination between (a) discursive practices, events and texts, and (b) wider social and cultural structures, relations and processes; to investigate how such practices, events and texts arise out of and are ideologically shaped by relations of power. As such, CDA examines the dual, reciprocal interplay of dialogic practices, events and textual constructions (in online environments) and broader social influences to understand their implications on social power. CDA is critical to the study of social / interactional power because discourse[s] are inherently part of, and influenced by social structure, and produced in social interaction (Van Dijk, 2003).

Several studies that have employed discourse analysis for exploring computermediated interaction, mobile instant messaging system, information and communication technology (ICT)-enhanced socio-economic development, education and spatial policy discourses (Richardson \& Jensen, 2003; Thompson, 2005; Ng'ambi, 2008; Chigona \& Chigona, 2008) have not explored SNSs. Moreover, a top down approach to discourse is evident in studies on public officials' speeches on the adoption of ICTs in emerging and advanced countries (Thompson, 2005; Roode, Speight, Pollock \& Webber, 2004). Resultantly, little is known about the interplay of lecturer-student and student-peer interactional power at micro levels in social networking environments (SNEs). To bridge this gap, this study adopts a macro-micro level approach (speech genres of educators and students on Facebook) to discourse analysis, to examine how textual interactions on Facebook are informed by both immediate interactional context (micro level factors) and broader social structural issues.

\section{Peculiarity of Facebook environment}

A CDA framework resonates with Facebook dialogic conversations because these dialogues tend to be replete with manipulative tendencies of writers (knowledgeable learners, educators) aimed at influencing the psychology and social behaviour of readers / communicants (peers) through normalising discourses. However, Facebook's dialogic complexity lies in the flexibility that communicants often have with regard to where to post their messages, who to engage with, and the language to use during interactions. Moreover, Facebook's peculiarity is predicated on its blurring of the divide between private and public discourse through 'imagined audiences' and 'collision of contexts' (Boyd, 2011). Facebook is also grounded in the connectivism framework of knowledge production that values connected networks, co-generation of knowledge by novices and experts and use of complex, adaptive systems for knowledge generation (Siemens, 2006). More so, the informal and unregulated conversations on Facebook raise critical questions about the exercise of academic authority and democratic expression of views when academics are involved.

SNE-carriers of ideological interests

Understanding the influence of SNSs on lecturer-student power relations is crucial to student meaningful learning because Facebook is not a value-free technology but rather an instrument for articulating power. Feenberg (2003) suggested that a productive way of conceiving technology is as human controlled and value-laden. As such, technological agents (lecturers and students) can deploy Facebook's text-based interactions ideologically to direct their interactants' (other lecturers, peers, extended academic community) actions and mental dispositions towards their intentions and 
interests - like exertion of academic authority - and to communicate their learning needs respectively (Rambe, 2011). As Rambe (2011) elaborates, power circulates through technology's (the medium) affordances and constraints and manifests through the actions and reactions of academics and learners.

Given the potential of SNSs to communicate intentions and ideologies (e.g. imposing social control, academic discipline, influencing academic philosophies/ perspectives, improving equitable access and contributions from learners), Facebook can be drawn upon to overcome a learner's sense of psychological powerlessness. As Koper \& Tattersall (2004) contend, making ICT facilities available is inadequate for ensuring that these facilities are applied effectively to overcome psychological barriers to learning, such as "poor family culture of learning, low aspiration, low self-esteem, bad childhood experience of learning" (Longworth, 2003). Addressing these barriers necessitates developing learning designs that meet the specific requirements for lifelong learning, including individual differences in needs, learning preferences, prior-knowledge and situational circumstances of learners (Koper \& Tattersall, 2004). Extending these authors' views I argue that eliminating students' psychological barriers necessitates academic understanding of technologies as carriers of ideological interests and their potential use for overcoming social control. As Ng'ambi (2011) observes, new technologies like anonymous mobile instant messaging can be appropriated in class to elicit the participation of subverted voices and shy, less confident students.

\section{Research questions}

Text-mediated discourse involves text messages and discursive practices (via a computer medium) among communicants who do not necessarily see one another facially. This implies that effects of physical presence like 'intimidating' social presence and voices of superior parties are made less explicit (Jaffe, Lee, Huang \& Oshagan, 1995; Kiesler, Siegel \& McGuire, 1984). Therefore, socially networked interaction between academics and learners may potentially democratise asymmetrical relations of power. Mindful of these dynamics, the following questions are posed:

1. What discursive types are activated by educator-learner engagement on Facebook and how do these inform understanding of higher education challenges?

2. How does interaction on SNS democratise or entrench power relations in educatorlearner and learner-peer interaction?

\section{Literature review}

Mark Zuckerberg, a Harvard University student and his colleagues created Facebook in 2004. Ridgway (2010) observes that Facebook was created in response to Harvard University's lack of a student image directory and served as an online social directory for college students. Facebook is a SNS with a CV-based online directory, which potentially supports individualised learning and collaborative engagement. Moore (2010) documented the rising academic application of SNS (Facebook, blogs, podcasts) at South African universities. These uses include sharing university related information, connecting with new and current learners, distributing news, and sharing academic content, individual thoughts and academic reflection. Although Moore's (2010) work illuminates understanding of how faculties are deploying SNS 
innovatively to foster collegiality and learning communities, his reflections are less insightful for grasping academic relations at micro levels. Boyd (2007) suggests that SNS have altered the underlying architecture of social interaction and information distribution due to their multiple communication channels and complex networks. She elaborates that these interaction dynamics have triggered moral panic for conservative academics and compelled optimistic educators to learn from technologically adept learners.

Few studies have examined micro-level academic relations in blended learning environments involving Facebook. Other studies affirm Facebook discussion forums' potential to break language and intercultural barriers to communication (Rambe, 2010; McCarthy, 2010). In his study of 147 first year architecture students' experiences of a blended learning environments (traditional lectures and Facebook), McCarthy (2010) reported that Facebook served as a serendipitous space to overcome language and intercultural barriers and first years' introversion. Facebook discussions created perfect opportunities for student extended engagement with peers' comments and critiques rather than being put on the spot in lectures. Unlike the university's learning management system (LMS), which is provided by the institution, Facebook is a ubiquitous technology for social use by students rather that an academic networking platform for their courses (Rambe, 2010). Therefore, Rambe (2010) reports that most students conceive Facebook as a self-regulated space for individual expression that is less amenable to rigid institutional controls compared with course-based LMS.

Social media are vital tools for rendering student voice and control over learning. McLoughlin and Lee (2010) articulate exemplars of productive deployment of web based tools and applications like Flickr, wikis, vodcasts, blogs and digital voice recorders to create personalised learning environments for student self-regulation of learning and giving them voice. They report that these tools can shift control to learners, through promoting agency, autonomy and engagement in social networks that straddle multiple real and virtual learning spaces. They recognise the need for educators to balance demands for the scaffolding of learner reflection and development of generic competencies with student privacy issues and feelings of being unwelcome in students' social networks.

Shih (2011) investigated a blended approach that integrated Facebook use and online peer-assessment to explore Facebook's influence on English writing skills of English majors at a Taiwanese university. The study reported that the blended approach generated student opportunities for experiencing the learning of English writing skills, and improved student willingness to interact and express their own ideas in writing. We infer that Facebook peer assessment boosted their psychological empowerment through heightening their linguistic confidence and communicative abilities. Facebook collaborative learning is rendered through expansion of transactional networks, joining affinity groups that exchange academic interests, and student connections to extended academic communities. Valenzuela, Park \& Kee (2008) project that SNSs promote the formation of common interest groups that help users coordinate collective action. They also allow regular exchanges between users, which can foster trust and norms of reciprocity that are key antecedents of [academic] community life (Valenzuela, Park \& Kee 2008 ). Facebook's academic value lies in opportunities it gives students to connect with classmates in large lectures; form study groups; find high school classmates on remote campuses; and develop a sense of community by finding students with similar interests (Bishop-Russell et al, 2006). Judging from these studies, our inference is that Facebook is about artefact sharing, academic networking and 
relationship building. At the heart of these social practices are the negotiation of knowledge and psychological dominance through hierarchical control of discourses.

\section{Critical discourse analysis (CDA)}

This paper is informed by Fairclough's $(1995,1989)$ critical discourse analysis. CDA is an analytical framework for unravelling opaque relationships between discourse and society as factors in securing power (Fairclough, 1995). For Fairclough (1989), CDA examines the discursive participants' choices of words and metaphors in relation to their relational, experiential, and expressive values, with these choices encoding assumption about power (cited in Orellana, 1996). Thus, through an examination of educator and learner Facebook text messages, discursive practices, and broader social context in which Facebook interaction unfolds, the negotiation and hidden manifestation of power can be grasped.

Fairclough (1989) identifies three levels of relational discourses as: (1) social conditions of production and interpretation, that is, factors in society that led to the production of texts and how these factors affect interpretation; (2) the process of production and interpretation, that is, how texts have been produced and this affects interpretation; (3) the product of the first two stages, the text. Corresponding to these levels of discourse, Fairclough (1989) prescribes three stages of CDA as:

- Description stage is concerned with the formal properties of text.

- Interpretation is concerned with the relationship between text and interaction emphasises conception of text as an outcome of production, and as a resource in the process of interpretation.

- Explanation is concerned with the relationship between interaction and social context - foregrounds the social determination of the processes of production and interpretation, and their social effects.

It is inferred that the context of interaction structures the flow of interaction and simultaneously, the interaction itself affords understanding of the context in which social interaction occurred. Therefore, there is a recursive, mutually reciprocal exchange between the broader social context of text production and textual properties. Overall, description is about the textual analysis, interpretation constitutes examination of discursive practices of the textual interaction, while explanation underscores broader social practices that frame the social interaction (Figure 1).

\section{Case study}

The study was conducted on first year information systems (IS) students at a middlesized, historically privileged, English-speaking university in South Africa. To meet the educational needs of diverse learners, the IS department blended face to face lecture delivery with an institutional learning management system (LMS) for the delivery of learning resources (lecture notes, slides, course outlines, reading lists and readings). Since collaborative learning on interactive applications (chat features, blogs, discussion forums) on the LMS was sub-optimally exploited, a Departmental Facebook environment was introduced by staff to leverage question-based educator-learner consultation and peer-based knowledge sharing. 


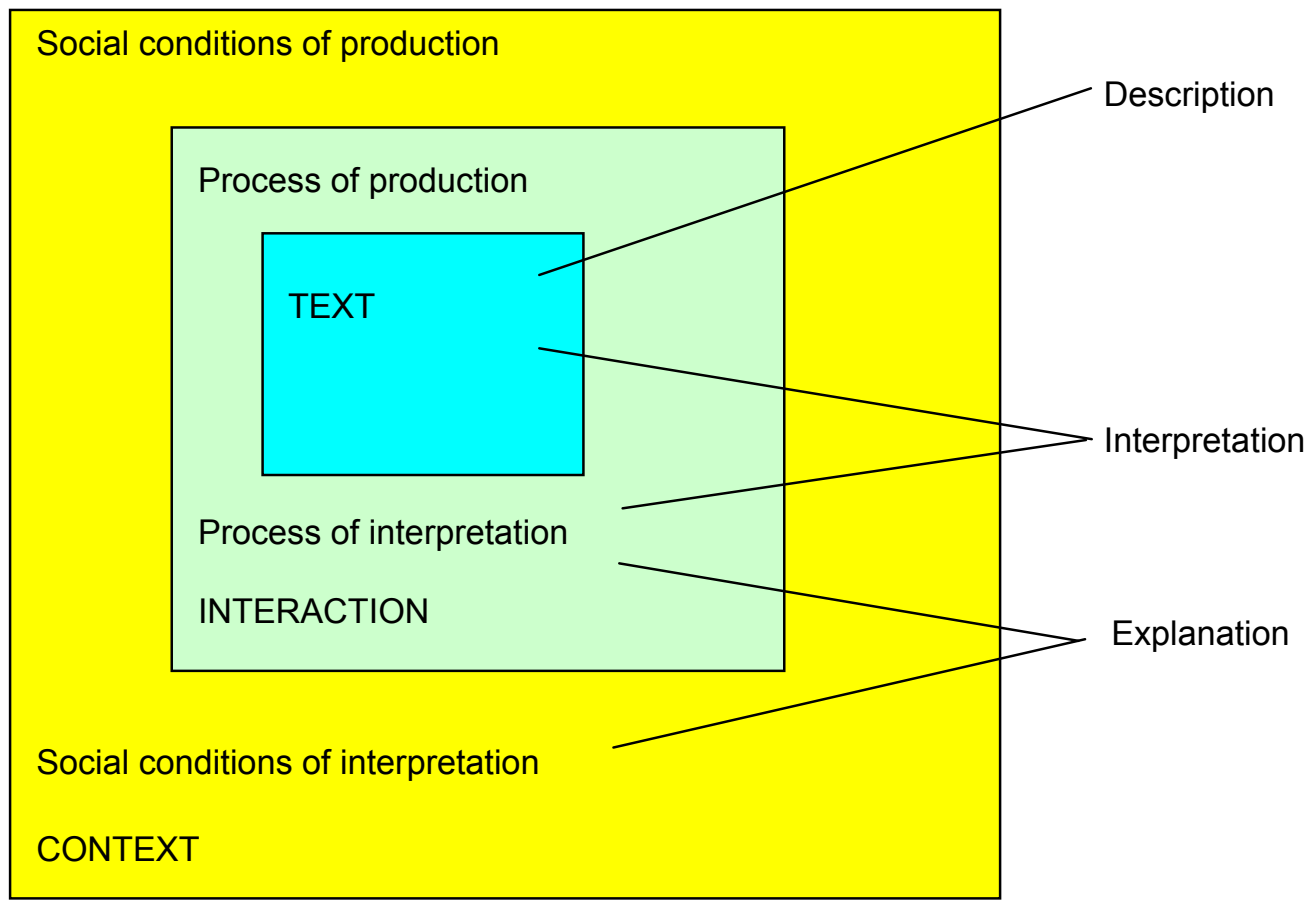

Figure 1: Discourse as text, interaction and context (after Fairclough, 1989; Thompson, 2005)

The first-year IS stream studied comprised about 450 learners whose lessons were conducted weekly in three groups. Two groups (clusters) comprised approximately 200 learners with fairly sophisticated ICT literacy skills while the third group comprised about 50 learners with limited or no experience with computers. These three groups covered the same lecture content. However, previously disadvantaged learners (the third group) were on an extended Academic Development Program (ADP) running for a year (INFO 1077B) while the other two groups accomplished the course within a semester (INFO1078A). These course codes are pseudonyms used to protect the identity of the courses. This coheres with the anonymity rule of this University's Code of Ethics for researching human subjects. Despite the heterogeneity in learner backgrounds and contact duration, all the learners had one main Facebook environment for question-based consultation with peers and lecturers.

The IS Department required learners to create personal Facebook accounts and join its Facebook group to activate student sustained participation. The course convenor designated one IS educator as an online administrator who addressed theoretical, practical and general course administration queries that learners posed to educators. The course convenor also maintained a social presence and occasionally addressed course administration queries on Facebook. The Department Facebook environment had three interactional spaces through which learners and educators interacted namely, the administrator's Facebook inbox for personal educator-learner consultation, Facebook discussion board, a special wall feature for public messages and discussions, and the Facebook wall, a public space for public discourse on academic matters. 


\section{Analysis of text messages}

Fairclough's (1995) analysis is informative for understanding the duality between structural conditions in the construction of discourse and the micro-level properties of text. He makes a distinction between generic "speech genres" (SG) or linguistic devices, which apply across various orders of discourses and "discursive types (DT) or themes - formations which are vertically identifiable as constitutive of a particular order of discourse and which are attributable to a given domain of study (Thompson, 2005). Discursive practices constitute the vital link between text and the broader social context of its production (the level at which discourses function). They constitute the discrete, unique utterances or combination of idioms, references, inferences or phrases within an order of discourse (Thompson, 2005).

Some authors (Thompson, 2005; Roode, Speight, Pollock \& Webber, 2004) employ Fairclough's categorisations of SG and DT to develop a characterisation of power in discourses. For example, Thompson (2005) combines a semi-grounded theory analysis on the development discourses on ICT adoption and Fairclough's vertical and horizontal (SG and DT) formulation to develop a logical description of how ICT for Development discourses are deeply implicated in configurations of power (see Tables 1 and 2). Each text genre (TG) corresponds to a particular category of discursive type as shown below. For example, utterances and information should be factual for them to be conceived as legitimating a given claim.

Table 1: Text genres and discursive types (adapted from Thompson, 2005, p. 7)

\begin{tabular}{|l|l|}
\hline \multicolumn{1}{|c|}{ Text genre (TG) } & \multicolumn{1}{c|}{ Discursive type (DT) } \\
\hline 1. Confidence & 1. Technocracy \\
\hline 2. Factual information & 2. Legitimacy \\
\hline 3. Humour & 3. Neutrality \\
\hline 4. Persuasion & 4. Corporatism \\
\hline & 5. Techno(logical) optimism \\
\hline & 6. Pragmatism \\
\hline
\end{tabular}

Neutrality discourse type adopts a middle of the road approach where the text message reflects no inclination to a given position or side. Mutual partnership and collaboration underscore the corporatism discursive type. Technological optimism discursive type stresses the affordances of technology in academic engagement, while pragmatism discursive type is located in the search for realistic or practical solutions. Legitimacy discursive type is founded on the expression of disciplinary authority while technocracy discursive type refers to "technocratic discourse" (Ng'ambi, 2008, p. 34). The text genres and discursive types all emerge from interaction of the three-tier hierarchy of description, interpretation and explanation. Hence, discursive types should not be taken in isolation but as functions of the recursive interaction of the micro and macro levels.

Thompson's (2005) analysis draws on data from the speech itself (Text column) to make a connection with identified discursive types and their description (Description column) towards the derivation of speech genres and discursive types (Interpretation) and their implications on power. Thompson's (2005) analysis, therefore, builds on Fairclough's analysis and semi-grounded theory approach to develop the following analytical framework (Table 2). 
Table 2: Analysis of raw data drawing on Fairclough's (1995) discursive framework (adapted from Thompson, 2005, p. 9)

\begin{tabular}{|l|l|l|l|}
\hline \multicolumn{1}{|c|}{ Micro } & \multicolumn{1}{c|}{ Link } & \multicolumn{1}{c|}{ Macro } \\
\hline Text: Introduction & $\begin{array}{l}\text { Description } \\
\text { (Text analysis) }\end{array}$ & $\begin{array}{l}\text { Interpretation } \\
\text { (Discursive practice) }\end{array}$ & $\begin{array}{l}\text { Explanation } \\
\text { (Social practice) }\end{array}$ \\
\hline $\begin{array}{l}\text { Excerpt of raw data } \\
\text { (the speech) }\end{array}$ & & & \\
\hline
\end{tabular}

My analytical framework involved the identification of TGs and DTs that emerged from Facebook textual messages. This process was accomplished using a semigrounded approach involving the adoption of first order and second concepts (Van Maanen \& Barley, 1985) from the Facebook postings. These concepts were iteratively processed until a set of refined concepts were developed.

Of the 450 first year students doing the IS course, a sample of 165 students posted 414 posts. They posted 154 wall posts, 121 discussion board posts, and 139 posts to the administrator's inbox. It is important to understand that several students' conversations with peers or the educator would contribute to one or several discursive types. The postings discussed constituted some generic comments posted by students and hence formed common threads throughout the conversations that appeared in the three discursive spaces. Postings comprised theoretical questions, procedural queries on practical exercises (the majority), course administration matters, social queries and compliments. These text messages were posted over approximately one year (two semesters).

\section{Analysis of results}

For brevity, I discuss the Facebook artefacts on theoretical, procedural and administrative matters as these were more dominant and conversational than other queries. Significantly, these queries related to student-student and academic-student collaborative engagement on academic matters and to the exercise of academic power, which constitute the thrust of this paper. While the characterisation of text genres and discursive types is an intra-subjective process, extracts of raw data are provided to allow for the critical reader's self evaluation.

\section{Discursive types on theoretical queries}

The first type of questions that students posed to the educator and that received the attention of their peers are theoretical questions. Students were challenged by complex concepts they failed to define for various reasons - ranging from patchy literature available in the library, limited information in the study guide, and a lack of clarity between these concepts and related concepts. Textual analysis (Table 3) depicts educator-learner collaboration on the theoretical concept of ergonomics. The other learner queries whether the concept falls within the broader framework of human computer interaction (HCI).

In the next text analysis (Table 4 below), a student bemoans the limited elaboration of theoretical concepts (systems thinking and system) in the textbook. She poses a question on the operationalisation of these concepts in the IS discipline. The educator's elaboration activates another question from another student on the constituent elements of systems thinking. The online administrator passionately engages with the 
student's questions and as the conversation reaches its climax, another student renders a website with relevant information for peer access.

Table 3: Text analysis of student queries on theoretical concepts on Facebook

\begin{tabular}{|c|c|c|c|}
\hline Text & $\begin{array}{c}\text { Description } \\
\text { (text genre) (TG) }\end{array}$ & $\begin{array}{c}\text { Interpretation } \\
\text { (discursive type) } \\
\text { (DT) }\end{array}$ & $\begin{array}{l}\text { Explanation } \\
\text { (social practice) }\end{array}$ \\
\hline $\begin{array}{l}\text { Discussion Board Post (DBP) } 111 . \\
\text { Hi Theron. I'd like to request some } \\
\text { guidance on my topic } 12.6 \\
\text { (ergonomics) and where I could } \\
\text { possibly find relevant info. Thank } \\
\text { you }\end{array}$ & $\begin{array}{l}\text { Persuasion } \\
\text { Learner implores the } \\
\text { educator for } \\
\text { information } \\
\text { Contraction "i'd" is } \\
\text { used instead of "i } \\
\text { would" to reflect the } \\
\text { informality of the } \\
\text { conversational } \\
\text { context. "Info" also } \\
\text { smacks of informality } \\
\text { Addressivity by first } \\
\text { name is not honorific }\end{array}$ & $\begin{array}{l}\text { Legitimacy } \\
\text { Educator is the } \\
\text { authoritative } \\
\text { source of } \\
\text { information }\end{array}$ & $\begin{array}{l}\text { Although the } \\
\text { educator's } \\
\text { designation as an } \\
\text { authoritative } \\
\text { source is implied } \\
\text { by reference to } \\
\text { "guidance", the } \\
\text { tone of the } \\
\text { consultation } \\
\text { process is quasi- } \\
\text { formal }\end{array}$ \\
\hline $\begin{array}{l}\text { DBP 112A. Working with your } \\
\text { computer can be productive, } \\
\text { rewarding and fun. Unfortunately, } \\
\text { prolonged postures, coupled with high } \\
\text { levels of concentration and the } \\
\text { occasional frustration of things going } \\
\text { less than perfectly, can lead to } \\
\text { physical problems }\end{array}$ & $\begin{array}{l}\text { Factual information } \\
\text { Technology-enhanced } \\
\text { productivity and } \\
\text { technological } \\
\text { disruptions }\end{array}$ & $\begin{array}{l}\text { Technological } \\
\text { optimism } \\
\text { The affordances } \\
\text { and disincentives } \\
\text { of technology are } \\
\text { acknowledged } \\
\text { Pragmatism } \\
\text { Using examples } \\
\text { students easily } \\
\text { relate to is fund- } \\
\text { amental to their } \\
\text { understanding }\end{array}$ & $\begin{array}{l}\text { Construction of } \\
\text { technology as both } \\
\text { liberating and } \\
\text { disciplining for the } \\
\text { users. } \\
\text { Explicit teaching is } \\
\text { a useful pedago- } \\
\text { gical strategy to } \\
\text { inform under- } \\
\text { prepared students } \\
\text { with learning } \\
\text { difficulties. }\end{array}$ \\
\hline $\begin{array}{l}\text { DBP } 112 \mathrm{~B} \text { [another learner] Does } \\
\text { that relate to HCI? }\end{array}$ & $\begin{array}{l}\text { Uncertainty } \\
\text { Unsure about which } \\
\text { discipline the concept } \\
\text { is located }\end{array}$ & $\begin{array}{l}\text { Neutrality } \\
\text { Rather than } \\
\text { agree or critique } \\
\text { the information } \\
\text { given, a peer } \\
\text { responds with } \\
\text { another question }\end{array}$ & $\begin{array}{l}\text { Reinforcement - } \\
\text { the learner seeks } \\
\text { clarification on an } \\
\text { issue (HCI) already } \\
\text { addressed }\end{array}$ \\
\hline $\begin{array}{l}\text { DBP 113. Yes. A basic understand- } \\
\text { ing of the way you "interface" with } \\
\text { your computer can help prevent } \\
\text { common health-related problems. } \\
\text { Some knowledge of the principles of } \\
\text { how people interact safely and } \\
\text { efficiently with machines and their } \\
\text { work environment, saves you from } \\
\text { discomfort and maximize both } \\
\text { productivity and enjoyment. This } \\
\text { is ergonomics.... }\end{array}$ & $\begin{array}{l}\text { Factual information } \\
\text { Educator gives } \\
\text { practical information }\end{array}$ & $\begin{array}{l}\text { Pragmatism } \\
\text { Practical } \\
\text { precautions on } \\
\text { health related } \\
\text { problems that } \\
\text { emerge from } \\
\text { HCI }\end{array}$ & \\
\hline
\end{tabular}


Table 4: Text analysis of student queries on theoretical concept on Facebook

\begin{tabular}{|c|c|c|c|}
\hline Text & $\begin{array}{c}\text { Description } \\
\text { (text genre) (TG) }\end{array}$ & $\begin{array}{c}\text { Interpretation } \\
\text { (discursive type) } \\
\text { (DT) }\end{array}$ & $\begin{array}{c}\text { Explanation } \\
\text { (social practice) }\end{array}$ \\
\hline $\begin{array}{l}\text { Facebook Inbox Posting (FIP) } \\
\text { 112A: hi Theron im just a bit } \\
\text { confused as to what my topic } \\
\text { entails for the literature } \\
\text { review. I'm doing "what is a } \\
\text { system? System thinking". } \\
\text { Which is 1.3! In the text book } \\
1.3 \text { is just about systems in } \\
\text { general and what their purpose } \\
\text { is...the info is not even a page } \\
\text { long! [Learner] }\end{array}$ & $\begin{array}{l}\text { Uncertainty and humour } \\
\text { Confusion is an } \\
\text { expression of } \\
\text { uncertainty. Confusion is } \\
\text { understated "a bit" as if } \\
\text { limited amounts of it are } \\
\text { not as delusional } \\
\text { Factual information } \\
\text { The content of a chapter } \\
\text { and the number of pages } \\
\text { is factual information }\end{array}$ & $\begin{array}{l}\text { Pragmatism } \\
\text { Understanding } \\
\text { that sufficient } \\
\text { background } \\
\text { information is } \\
\text { necessarily to } \\
\text { adequately } \\
\text { answer a question }\end{array}$ & $\begin{array}{l}\text { Textbook given as } \\
\text { a prime canonical } \\
\text { source }\end{array}$ \\
\hline $\begin{array}{l}\text { FIP } 112 \text { B: Simply put, a system } \\
\text { is an organized collection of } \\
\text { parts that are highly } \\
\text { integrated to accomplish an } \\
\text { overall goal. The system has } \\
\text { various inputs, which go } \\
\text { through certain processes to } \\
\text { produce certain outputs, [...]. } \\
\text { [Admin Response] }\end{array}$ & $\begin{array}{l}\text { Factual information } \\
\text { The definition of the term } \\
\text { is factual }\end{array}$ & $\begin{array}{l}\text { Corporatism } \\
\text { Expresses her } \\
\text { desire to elaborate } \\
\text { concepts to } \\
\text { leverage student } \\
\text { understanding }\end{array}$ & $\begin{array}{l}\text { Hierarchical } \\
\text { discourses are } \\
\text { reproduced as } \\
\text { technological } \\
\text { cognoscenti frame } \\
\text { discursive } \\
\text { practices in which } \\
\text { students are } \\
\text { functionally } \\
\text { passive recipients } \\
\end{array}$ \\
\hline $\begin{array}{l}\text { FIP 111A: [learner name] } \\
\text { Thanks Theron. But Im not sure } \\
\text { if im supposed to be talking } \\
\text { about systems generally or } \mathrm{i} \\
\text { must say what an information } \\
\text { system is as well. Please can } \\
\text { you help me. Thanx very much }\end{array}$ & $\begin{array}{l}\text { Persuasion } \\
\text { The information need is } \\
\text { expressed in form of a } \\
\text { plea. The compliments } \\
\text { entrench the persuasive } \\
\text { approach }\end{array}$ & $\begin{array}{l}\text { Corporatism } \\
\text { The two compli- } \\
\text { ments demonstr- } \\
\text { ate learner corpor- } \\
\text { atism and apprec- } \\
\text { iation of the edu- } \\
\text { cator's messages }\end{array}$ & $\begin{array}{l}\text { Passive reception } \\
\text { with limited } \\
\text { critical engage- } \\
\text { ment undermines } \\
\text { student intellectual } \\
\text { growth and self- } \\
\text { regulation }\end{array}$ \\
\hline $\begin{array}{l}\text { FIP 111B: For example, an } \\
\text { organization is made up of } \\
\text { many administrative and } \\
\text { management functions, } \\
\text { products, services, [...]. If one } \\
\text { part of the system is changed, } \\
\text { the nature of the overall } \\
\text { system is often changed, as } \\
\text { well - [...]. (This is not to be } \\
\text { confused with systematic, which } \\
\text { can mean merely that something } \\
\text { is methodological. Thus, } \\
\text { methodological thinking - } \\
\text { systematic thinking -- does not } \\
\text { necessarily mean systems } \\
\text { thinking.) }\end{array}$ & $\begin{array}{l}\text { Confidence } \\
\text { The academic confides in } \\
\text { the student by } \\
\text { distinguishing } \\
\text { organisational system } \\
\text { from systemic thinking. } \\
\text { The sentence is framed by } \\
\text { distantiation "this is not } \\
\text { to be confused" }\end{array}$ & $\begin{array}{l}\text { Legitimacy } \\
\text { The educator } \\
\text { assumes an } \\
\text { authoritative } \\
\text { voice by } \\
\text { deconstructing } \\
\text { and contrasting } \\
\text { concepts }\end{array}$ & $\begin{array}{l}\text { Replication of } \\
\text { educator's } \\
\text { academic status as } \\
\text { dominant } \\
\text { information } \\
\text { disseminator. } \\
\text { "This is not to be } \\
\text { confused with" is } \\
\text { normalising and is } \\
\text { negative framing } \\
\text { of authority }\end{array}$ \\
\hline $\begin{array}{l}\text { FIP } 110 \text { [Another student ] } \\
\text { You can find this information } \\
\text { on this IT website [URL link } \\
\text { provided] }\end{array}$ & Factual information & & \\
\hline
\end{tabular}




\section{Discursive types on study management and procedural problems}

Students seemed to over rely on books for academic survival. The collaboration among the educator and students seemed to expose this academic orientation (see text analysis in Table 5).

Table 5: Text analysis of logistic problems

\begin{tabular}{|l|l|l|l|}
\hline \multicolumn{1}{|c|}{ Text } & $\begin{array}{l}\text { Description } \\
\text { (text genre) (TG) }\end{array}$ & $\begin{array}{l}\text { Interpretation } \\
\text { (discursive type) } \\
\text { (DT) }\end{array}$ & $\begin{array}{l}\text { Explanation } \\
\text { (social } \\
\text { practice) }\end{array}$ \\
\hline $\begin{array}{l}\text { DBP 80A: [Learner] Hi [Theron], I have been } \\
\text { assigned topic 2.6 for the literature review but } \\
\text { there is one slight problem. I cannot find any } \\
\text { information about the importance of } \\
\text { hardware standards and I have been looking } \\
\text { for a couple of days }\end{array}$ & $\begin{array}{l}\text { Humour } \\
\text { In spite of little } \\
\text { success in acc- } \\
\text { essing inform- } \\
\text { ation, a humor- } \\
\text { ous understate- } \\
\text { ment "slight } \\
\text { problem" is } \\
\text { employed }\end{array}$ & $\begin{array}{l}\text { legitimacy } \\
\text { Student } \\
\text { legitimately } \\
\text { seeks guidance } \\
\text { from a } \\
\text { disciplinary } \\
\text { authority }\end{array}$ & $\begin{array}{l}\text { Appeal to } \\
\text { academic } \\
\text { authority for } \\
\text { support }\end{array}$ \\
\hline $\begin{array}{l}\text { DBP 80B: Hi [learner name given], you need to } \\
\text { read articles on related topic...not just the } \\
\text { textbook. There is much work covered on this } \\
\text { subject in IS related journals/ books. The } \\
\text { primary considerations for any hardware } \\
\text { configuration are: ease of connectivity to a given } \\
\text { network; connectivity to external systems and } \\
\text { organizations; consistent performance of all } \\
\text { integrated components in our networked } \\
\text { environment; successful in-house experience with } \\
\text { the chosen product and configuration; maximum } \\
\text { period of machine functionality etc. }\end{array}$ & $\begin{array}{l}\text { Confidence } \\
\text { "there is much } \\
\text { [Administrator's response] } \\
\text { covered on..." } \\
\text { Educator } \\
\text { confides in the } \\
\text { student that } \\
\text { wide readership } \\
\text { and } \\
\text { diversification of } \\
\text { sources is crucial } \\
\text { for academic } \\
\text { survival }\end{array}$ & $\begin{array}{l}\text { Pragmatism } \\
\text { "read articles on } \\
\text { the topic... not } \\
\text { just the text } \\
\text { book". } \\
\text { Academic } \\
\text { performance is } \\
\text { constructed } \\
\text { around the } \\
\text { consultation and } \\
\text { mastery of } \\
\text { information } \\
\text { from diverse } \\
\text { sources }\end{array}$ & $\begin{array}{l}\text { Provision of } \\
\text { strategic } \\
\text { direction on } \\
\text { information } \\
\text { sources is } \\
\text { another } \\
\text { mandates of } \\
\text { an academic } \\
\text { authority }\end{array}$ \\
\hline
\end{tabular}

The textual constructions above on study processes demonstrate that although students generally understood the lecturer's expectations on assignments, they lacked the appropriate study and information management skills to execute them. They also struggled with procedural tasks like the working of percentiles and quartiles as shown in Table 6.

\section{Administrative questions}

Facebook also afforded students the opportunity to pose administrative queries. They collaborated on common administrative problems they faced and expressed their reservation about the the department's management of these issues (Table 7 below).

\section{Discussion}

\section{Shallow approaches to learning}

Educator-learner engagement on Facebook exposed student surface approaches to learning like their reliance on textbooks and educator support in university education. Some Facebook consultations demonstrated learners' inability to diversify their information sources beyond what the educator provided. 
Table 6: Text analysis of procedural problems

\begin{tabular}{|c|c|c|c|}
\hline Text & $\begin{array}{c}\text { Description } \\
\text { (text genre) (TG) }\end{array}$ & $\begin{array}{c}\text { Interpretation } \\
\text { (discursive type) } \\
\text { (DT) }\end{array}$ & $\begin{array}{c}\text { Explanation } \\
\text { (social practice) }\end{array}$ \\
\hline $\begin{array}{l}\text { FIP. 119A: Hi. Please tell me how we } \\
\text { should work out the PERCENTILE } \\
\text { and QUARTILE staff. }\end{array}$ & $\begin{array}{l}\text { Persuasion } \\
\text { Pleading with the } \\
\text { expert for academic } \\
\text { support }\end{array}$ & $\begin{array}{l}\text { Pragmatism } \\
\text { Quest for a practical } \\
\text { solution }\end{array}$ & $\begin{array}{l}\text { Appeal to } \\
\text { academic } \\
\text { authority on } \\
\text { procedural } \\
\text { matters }\end{array}$ \\
\hline $\begin{array}{l}\text { FIP. 119B: This example i am giving } \\
\text { you below is based on the work you did } \\
\text { in the lab on Thursday last week. To } \\
\text { calculate the percentile, the pth } \\
\text { percentile has p\% of the data below } \\
\text { it. For example, the median is the } \\
\text { 50th percentile. To calculate the } \\
\text { price at the 5th percentile you use } \\
\text { the following formula: = } \\
\text { percentile(price, } 0.05 \text { ). To calculate } \\
\text { the price of the first quartile (the } \\
\text { 25th percentile) you use = } \\
\text { quartile(price,1) } \\
\text { Hope this helps, Cheers }\end{array}$ & $\begin{array}{l}\text { Factual information } \\
\text { Reference to a } \\
\text { previous event-lab } \\
\text { exercise and the } \\
\text { procedural } \\
\text { calculation are all } \\
\text { factual expressions } \\
\text { The colloquialism } \\
\text { "cheers" } \\
\text { demonstrates the } \\
\text { quasi-formal nature } \\
\text { of conversations }\end{array}$ & $\begin{array}{l}\text { Corporatism } \\
\text { The elaborate } \\
\text { response } \\
\text { demonstrates that } \\
\text { the educator } \\
\text { cooperates with the } \\
\text { student } \\
\text { Pragmatism } \\
\text { The calculation is a } \\
\text { practical solution to } \\
\text { novel procedural } \\
\text { concepts learners } \\
\text { struggle with }\end{array}$ & $\begin{array}{l}\text { Facebook } \\
\text { visualises } \\
\text { student } \\
\text { problems. } \\
\text { Learner's limited } \\
\text { understanding is } \\
\text { exposed. }\end{array}$ \\
\hline
\end{tabular}

Their Facebook discursive practices illustrated dependence on primary texts (textbook and study guides) for the information necessary to accomplish procedural tasks and theoretical problems. The challenge of the over-reliance on books and stories is that [they] are decontextualised, the story and the illustration can be manipulated (Macdonald, 1987; 1990) thus distorting knowledge generation for under-prepared students. Moreover, since most questions were task or course administration-related, the administrators' responses were often similar and sometimes the responses were duplicated. Superficial learning also manifested in student failure to strategically harness Facebook discussions threads as information repositories for tracking the evolution of discussions, hence the tendency to repeat queries and responses. This redundancy was also caused by lecturer-student private conversations through Facebook private inbox messages/chats which constrained access to some students. Resultantly, the lecturer required all students to use the public Facebook discussion board to ensure the whole class benefited.

Teaching approaches that emphasise 'rote' learning and not transformation were alluded to in the quotation: "... Educators put no emphasis on what is important instead they rumbled on and it is impossible to remember everything they said (DBP 21)". Due to limited contact time, a complex trade-off emerged between syllabus completion and meaningful engagement with students. Rote learning is embodied in the emphasis on memorising content as demonstrated in the aforementioned statement. As such, educator-student class contact was not always productive. As Karpov \& Haywood (1998) suggest, rote skills are meaningless and non-transferable and hence learners should develop their own empirical knowledge to deal with subject domain problems. However, I contend that developing own knowledge can be complex for first year students and hence may require academic scaffolding in their critical thinking. 
Table 7: Text analysis of administrative issues

\begin{tabular}{|c|c|c|c|}
\hline Text & $\begin{array}{c}\text { Description } \\
\text { (text genre) (TG) }\end{array}$ & $\begin{array}{l}\text { Interpretation } \\
\text { (discursive } \\
\text { type) (DT) }\end{array}$ & $\begin{array}{l}\text { Explanation } \\
\text { (social practice) }\end{array}$ \\
\hline $\begin{array}{l}\text { DBP 21: IS in general was } \\
\text { poorly run. The MC [multiple } \\
\text { choice] quizzes are a good } \\
\text { concept however even after } \\
\text { attending the arduous and } \\
\text { boring lectures I had to guess } \\
\text { most questions. They were } \\
\text { vague and the textbook is too } \\
\text { long to bother for just a } 5 \\
\text { minute test. Educators put no } \\
\text { emphasis on what is important } \\
\text { instead they rumbled on and } \\
\text { it is impossible to remember } \\
\text { everything they said. [...] trying } \\
\text { to learn MS office in } 2 \text { sessions } \\
\text { was difficult, and watching } \\
\text { educators who know what they } \\
\text { themselves are doing didn't } \\
\text { help. [Learner name] }\end{array}$ & $\begin{array}{l}\text { Unapologetic (New TG) } \\
\text { The student makes no apology } \\
\text { for his reliance on guess work } \\
\text { Factual information } \\
\text { Length of textbook, and } \\
\text { duration of the quiz and } \\
\text { number of Microsoft Office } \\
\text { sessions are factual } \\
\text { expressions } \\
\text { Critical (New TG) } \\
\text { Student is critical of educator's } \\
\text { perceivably superficial } \\
\text { approaches that undercut } \\
\text { emphasis on essential } \\
\text { information. He critiques the } \\
\text { lack of experiential learning in } \\
\text { lectures / demonstrations }\end{array}$ & $\begin{array}{l}\text { Legitimacy } \\
\text { Student raises } \\
\text { legitimate } \\
\text { issues about } \\
\text { limitations of a } \\
\text { transmission } \\
\text { approach } \\
\text { Pragmatism } \\
\text { Student is more } \\
\text { intrigued by } \\
\text { hands on } \\
\text { approach to } \\
\text { solving } \\
\text { technical } \\
\text { problems }\end{array}$ & $\begin{array}{l}\text { Weak academic } \\
\text { literacies } \\
\text { manifest in } \\
\text { superficial } \\
\text { engagement } \\
\text { with content, } \\
\text { over-reliance on } \\
\text { primary texts } \\
\text { and limited } \\
\text { student } \\
\text { experimentation } \\
\text { with technology }\end{array}$ \\
\hline $\begin{array}{l}\text { DBP 19: The lectures were so } \\
\text { boring. I didn't attend them } \\
\text { and I and am not prepared to } \\
\text { study a whole chapter just for a } \\
5 \text { min test. Half of the } \\
\text { questions were out of the } \\
\text { syllabus, and even too hard } \\
\text { for the tutors. Vula [an LMS] } \\
\text { itself had many problems like } \\
\text { one week it crashed and } \\
\text { other times you got given } 8 \\
\text { options for a MCQ (multiple } \\
\text { choice quiz). [...]. And the } \\
\text { MCQs were just another } \\
\text { problem with IS. No offence } \\
\text { to anyone but yeah the quizzes } \\
\text { sucked [learner name] }\end{array}$ & $\begin{array}{l}\text { Unapologetic (New TG) } \\
\text { Student expressed no remorse } \\
\text { for missing lectures } \\
\text { Factual information } \\
\text { The questions out of the } \\
\text { syllabus, number of quiz } \\
\text { options and that the LMS was } \\
\text { offline is all factual } \\
\text { information } \\
\text { Humour } \\
\text { That tutors struggled with the } \\
\text { questions as a justification for } \\
\text { under-performance is } \\
\text { humorous and unapologetic } \\
\text { Emotive (New TG) } \\
\text { "No offence... yeah the quizzes } \\
\text { sucked!” sounds emotive }\end{array}$ & $\begin{array}{l}\text { Pragmatism } \\
\text { Absconding } \\
\text { quizzes was a } \\
\text { pragmatic way } \\
\text { of diverting } \\
\text { attention to } \\
\text { other academic } \\
\text { commitments - } \\
\text { practical but } \\
\text { tactless strategy } \\
\text { Legitimacy } \\
\text { The student } \\
\text { had legitimate } \\
\text { complaints } \\
\text { about } \\
\text { administrative } \\
\text { problems like } \\
\text { being offline, } \\
\text { vague quiz } \\
\text { questions }\end{array}$ & $\begin{array}{l}\text { Under- } \\
\text { developed } \\
\text { literacy practices } \\
\text { manifest in poor } \\
\text { attendance of } \\
\text { lectures, missing } \\
\text { quizzes, and } \\
\text { poor } \\
\text { information } \\
\text { management } \\
\text { and synthesis } \\
\text { skills }\end{array}$ \\
\hline
\end{tabular}

\section{Hierarchical discourses}

Student self-access to online resources is foundational for constructivist learning. However, the nascence of learner critical engagement with content tended to reinforce the silo knowledge production model that reproduced the legitimate authority of the educator as the authoritative voice. Although learners conceived peers as vital information givers on administrative and a handful of procedural matters, engagement with theoretical queries remained the domain of the educator. 
Hierarchical discourses, however, were sometimes replicated at student-peer levels as academically able students were affirmed by the educator as academically competent. This way, Facebook sometimes reproduced and entrenched hierarchical power relations between students. As Rose (2005) suggests, relations between students within every classroom and school, are unequal. As a result, the learner identities that are produced and maintained by the moral order of the classroom and school are stratified as successful, average or unsuccessful. This inequality is construed as differences in learning ability (Rose, 2005).

\section{Liberating discourses}

Contrary to LMS discussion forums, which are often lecturer-driven and framed by formal language, Facebook discussions employed quasi-formal language (informal greetings, colloquialism) and even student directive language like "please give me...". The addressivity was informal and non-hierarchical, involving the use of the lecturer's first name rather than her title. While traditional discussion forums often involve vertical dissemination of formal, decontextualised content, Facebook was pervaded by opportunistic peer-based collaboration and recursive student talk-back processes that gave students a voice. As Fairclough (1989) suggests, power manifests 'behind' discourse through efforts to standardise language forms or impose specific language formats and this limits who speaks, who is heard, and about what. That said, the casual Facebook conversations combined with limited academic maturity of some students (first years) often constrained the coherent expression of queries.

Liberating discourses also manifested in student ability to critique academics on matters of course administration. Facebook allowed students to openly question the department's course administration processes. They critiqued educators' pedagogical practices when their identities were conceivably 'hidden,' what they could not otherwise do in face to face contacts. One such critique was lectures' lack of focus which contributed to student difficulty in addressing weekly quizzes, which were supposedly based on them. CDA was therefore critical to exploring how students subtly employed textual language and discursive practices to question the taken for granted, but opaque departmental and problematic instructional practices. These talk back practices enabled public expression and negotiation of interactional power with lecturers through discourse.

Student critique of departmental practices illustrates SNS interaction's potential to subvert vertical relations of power and equalise educator and student access to knowledge claims. This critique supports claims about the power of computer mediated communication (Facebook) to democratise communication through filtering cues that denote social hierarchies (Short et al., 1976). Learners who could not otherwise criticise educators' academic practices in face to face contact for fear of sanction, found in Facebook a safe haven to question them.

\section{Nascent networked learning culture}

Networked technology is reported to enable e-learning, which gives learners access to resources such as online encyclopaedia, notes, tests, projects assignments, as well as group interactions (Mlitwa \& Nonyane, 2008). The emergent peer-based networking on Facebook suggests the value of learning networks for information sharing among students. Students discussed with peers issues ranging from course administration, 
procedural task execution to micro-level management of their daily lives. These social practices demonstrate the potential of Facebook networks to complement classroom practices by creating student learning communities for knowledge generation. As the literature suggests in these [learning] communities, learners participate actively, creating and sharing activities, learning plans, resources, and experiences with peers and institutions (Koper \& Sloep, 2002). Facebook therefore, presented a platform for learner practice with collaborative networking- for example through exchange of procedural information. As literature suggests in relation to ICTs context of use, when some [learners] are introduced to an ICT curriculum, they may already have taught themselves the skills in a non-formal setting, and furthermore they may know a great deal more than the teacher herself (Macdonald, 2006, p. 67). While learners acquired some ICT skills through informal interaction, my findings differ from Macdonald (2006) in that many of them proved not to be technophiles as the educator remained their main source of information.

\section{Visibility of common problems and camaraderie}

By viewing peers' questions, students gained confidence in posting questions as they realised that they were not the only ones with problems in grasping theoretical and procedural issues of the subject. Mlitwa \& Nonyane (2008) contend that ICT helps improve schools administration needs such as the registration of learners, keeping and retrieving of learner records and electronic (rather than manual) handling of marks, and enables teachers and learners to gain easy access to learning and teaching materials online across time divides. Access to learning resources was improved as they engaged with peer-generated text genres and interpreted them in diverse forms to inform their understanding of IS discourses. Discursive practices on issues they could easily relate to activated and sustained a culture of camaraderie. This is because they could identify with peers' problems and with the collective space where text genres were generated, viewed, responded to and critiqued.

\section{Conclusion}

Collaborative engagement on Facebook activated hierarchical and horizontal discourses that had a bearing on pedagogical instruction. Hierarchical discourses manifested in explicit teaching through educator elaboration of theoretical and procedural issues to learners and silo knowledge production models oriented towards textbook based research. These discourses exposed common student problems like weak study skills, challenges of synthesising and managing information, and poor management of time. From an instructor viewpoint, educator-student and student-peer interaction on Facebook afforded academics a panoramic view of students's mindsets, particularly their underdeveloped literacies. These literacies needed academic scaffolding to strategically align their teaching practices with students' learning strategies and learning needs.

Some students conceived educators as the predominant authoritative source of information. The lecturer-student discursive practices thus reproduced hierarchy and hegemonic dominance of the teacher over students. Such discourses were further reinforced by lecturers' affirmation of some "academically able" students' contributions, thus reconstructing academic categories of the 'academically powerful' and 'challenged.' Horizontal discourses that were conceivably liberating emerged through student collaboration with peers on procedural tasks. These collaborative 
discursive practices illustrate connectivism - that is, how learners connect and collate diverse content and conversation fragments to create an integrated (through sometimes) contradictory network of information (Siemens \& Tittenberger, 2009). As they reiterate, information acquisition is a mashup of dialogical pieces, reframing, rethinking, and developing connections to produce knowledge (p. 5). Similarly, Facebook discourses presented opportunities for student collaboration with both peergenerated content and pedagogical content knowledge.

Facebook potentially democratises academic relations by rendering students the agency to hold academics accountable as legitimate knowledge builders and givers and to intermittently neutralise their exercise of authoritative power. Yet such disruptions of asymmetrical power were circumstantial and often circumscribed by students' heavy dependence on the educator for academic support on theoretical and practical tasks. Transcending Siemens \& Tittenberger's (2009) view, it can be inferred that horizontal discourses ironically reproduced differential power structures as academics unconsciously conferred academic power to academically able students by affirming their answers as correct and convincing.

The two discourses mentioned above have fundamental implications for pedagogical practice in higher education:

- Academics should induct students into critical engagement, locating and interpreting the philosophy and ideologies behind different discourses they and peers activate. This could unlock student understanding of how disciplinary knowledge is constructed rather than passive reception of educator-generated content.

- Educators should encourage learner discursive practices involving higher forms of knowledge (theoretical knowledge) as much as they deliberate on procedural issues. Facebook learning communities could be employed as vehicles for deconstructing theoretical propositions and perspectives through text-based interaction. As Salmon's (2000) five stage model of e-learning posits, it is the higher levels knowledge construction and development that allow for student selfregulation of on-task activities, responsibility for knowledge construction and cognitive growth.

- Weak study skills and over dependence on educators for information are addressed by developing an information sharing culture and valuing the strength of student contributions during collaboration. Through this, students learn to become principal knowledge brokers than information receivers.

CDA exposed some hidden assumptions about power and implicit ideologies behind the discursive practices articulated on Facebook. Through an examination of text, its discursive types and the discourses invoked, subjective interpretations were made and the connections between the text, the settings in which discourses unfolded and the broader social context in which they unfolded became more apparent. Hierarchical discourses between the experienced expert and the novices were sometimes manipulation as some students failed to critically engage with the theoretical content. Van Dijk (2006) suggested that discourses become manipulative when the recipients are unable to understand the manipulator's real intentions or the consequences of the manipulator's beliefs or actions. This is often the case especially when the recipients lack the specific knowledge that might be used to resist manipulation (Wodak, 1987). 
For first year learners, engaging with educators' authoritative discourses necessitate their understanding of the IS field for them to interpret and critique her ideas in Facebook public spaces. That said, the educator's pragmatic approach to discourses on procedural queries allowed learners to approach her advice with an open mind. CDA's capacity to project different representations of discourses, various levels of discursive practices (text genres, discursive types and discourses) offer a compact analytical framework for IS practitioners intrigued by solving problems in IS implementation, IS strategy implementation, and general decision making on IS applications.

\section{Acknowledgment}

This article is a revised version of a paper titled "Critical discourse analysis of collaborative postings on Facebook", presented at the International Development Informatics Association Conference held at the University of Cape Town, Nov 2010. Preprint URL http: / / independent.academia.edu/PatientRambe/Papers / 1303092/Crit ical_discourse_analysis_of_collaborative_postings_on_Facebook (Rambe, 2010)

\section{References}

Boyd, D. (2011). Embracing a culture of connectivity. Webcast. Berkman Center for Internet and Society, Harvard University [verified 14 Mar 2012] http:/ / cyber.law.harvard.edu/interactive/events/2011/05/ danahboyd

Boyd, D. (2007). Social network sites: Public, private, or what? The Knowledge Tree, 13. [verified 14 Mar 2012] http:/ / kt.flexiblelearning.net.au/tkt2007 / ?page_id=28

Bishop-Russell, J., Dubord, M., Hansen, E. \& Webster, K. (2006). Acknowledging a campus.com(munity): [thefacebook] and diversity college. The University of Maine. [verified 14 Mar 2012] http:/ / www.studentaffairs.com/vcs/2006entries/UniversityofMaine.ppt

Centre for Educational Technology (2010). Projects. [viewed 12 Mar 2012] http: / / www.cet.uct.ac.za/ projects

Chigona, A. \& Chigona, W. (2008). Mix it up in the media: Media discourse analysis on a mobile instant messaging system. The Southern African Journal of Information and Communication, Issue 9, 42-57.

Facebook blog (2011). Facebook statistics [viewed 11 Jun 2011] http: / / www.facebook.com/ press/info.php?statistics

Fairclough, N. L. (1995). Critical discourse analysis: The critical study of language. Harlow, UK: Longman.

Fairclough, N. L. (1995). Media discourse. London: Edward Arnold.

Fairclough, N. L. (1989). Language and power. New York: Longman.

Feenberg, A. (2003). What is philosophy of technology? Lecture for the Komaba undergraduates, June 2003. http: / / www.sfu.ca / andrewf / books / What_is_Philosophy_of_Technology.pdf

Guess, A. (2008). Taking Facebook back to campus. Inside Higher Ed, 24 October. http: / / www.insidehighered.com/news/2008/10/24/ socialweb

Jaffe, M., Lee, Y., Huang, L. \& Oshagan, H. (1995). Gender, pseudonyms and CMC: Masking identities and baring souls. Paper submitted for presentation to the 45th Annual Conference of the International Communication Association, Albuquerque, New Mexico, USA. [verified 15 Mar 2012] http: / / www.fragment.nl/ mirror / Jaffe1995 / 
Karpov, Y. V. \& Haywood, H. C. (1998). Two ways to elaborate Vygotsky's concept of mediation: Implications for instruction. American Psychologist, 53(1), 27-36. http: / / psycnet.apa.org/ doi/10.1037/0003-066X.53.1.27

Kiesler, S., Siegel, J. \& McGuire, T. W. (1984). Social psychological aspects of computer-mediated communication. American Psychologist, 39(1), 1123-1134. http: / / psycnet.apa.org/ doi / 10.1037/0003-066X.39.10.1123

Kolek, E. A. \& Saunders, D. (2008). Online disclosure: An empirical examination of undergraduate Facebook profiles. Journal of Student Affairs Research and Practice, 45(1), 1-25. http: / / journals.naspa.org/jsarp/vol45/iss1/art2/

Koper, R. \& Tattersall, C. (2004). New directions for lifelong learning using network technologies. British Journal of Educational Technology, 35(6) , 689-700. http: / / onlinelibrary.wiley.com/doi/10.1111/j.1467-8535.2004.00427.x/ abstract

Koper, R. \& Sloep, P. B. (2002). Learning networks connecting people, organizations, autonomous agents and learning resources to establish the emergence of effective lifelong learning. RTD Programma into Learning Technologies 2003-2008. Heerlen: Open Universiteit Nederland. http:// hdl.handle.net/1820/65

Longworth, N. (2003). Lifelong learning in action: Transforming education in the 21st century. London: Kogan Page.

Macdonald, C. A. (2006). The properties of mediated action in three different literacy contexts in South Africa. Theory \& Psychology, 16(1), 51-80. http: / / dx.doi.org/10.1177/0959354306060109

Macdonald, C. A. (1990). Crossing the threshold into Standard Three in black education: The main report of the Threshold Project. Pretoria: Human Sciences Research Council.

Macdonald, C. A. (1987). Le Bonniec's alethic modality: A cross-cultural investigation. Unpublished MS. Pretoria: Human Sciences Research Council.

McCarthy, J. (2010). Blended learning environments: Using social networking sites to enhance the first year experience. Australasian Journal of Educational Technology, 26(6), 729-740. http: / / www.ascilite.org.au/ajet/ajet26/mccarthy.html

McLoughlin, C. \& Lee, M. (2010). Personalised and self regulated learning in the Web 2.0 era: International exemplars of innovative pedagogy using social software. Australasian Journal of Educational Technology, 26(1), 28-43. http: / / www.ascilite.org.au/ajet/ajet26/mcloughlin.html

Mlitwa, N. B. \& Nonyane. J. N. (2008). The status of ICT access and use in South African Schools: Comparing the rural and urban schools in the Mpumalanga Province. In Proceedings e/merge 2008, 7-18 July 2008. http:/ / emerge2008.net/ access/content/group/emerge2008/ PresentationFiles/Mlitwa/Access_in_Schools.pdf

Moore, D. (2010). Join the conversation: How (some) South African universities are using social media. Creative Commons PowerPoint Presentation. [verified 15 Mar 2012] http: / / www.slideshare.net/ weblearning/ south-african-universities-and-social-media

$\mathrm{Ng}$ 'ambi, D. (2011). Enhancing student interaction in didactic teaching approaches - the right to text during class. In Proceedings of the 6th International Conference on E-learning, University of British Columbia, Kelowna, Canada, 27-28 June 2011. Academic Publishing International Ltd.

Ng'ambi, D. (2008). A critical discourse analysis of students' anonymous online postings. International Journal of Information and Communication Technology Education, 4(3), 31-39. http: / / dx.doi.org/10.4018/jicte.2008070104 
Orellana, M. F. (1996). Negotiating power through language in classroom meetings. Linguistics and Education, 8(4), 335-365. http:/ / dx.doi.org/10.1016/S0898-5898(96)90016-9

Rambe, P. (2010). Social cultural discourse analysis of collaborative learning in Facebook postings. Presented at the 4th International Development Informatics Association Conference (IDIA) 2010, Exploring success and failure in development informatics: Innovation, research and practice, 3-5 November 2010, Cape Town, South Africa. http: / / www.developmentinformatics.org/conferences / 2010/papers/rambe.html

Rambe, P. (2011). Exploring the impacts of social networking sites on academic relations in the university. Journal of Information Technology Education, 10, 271-293. http: / / www.jite.org/documents/Vol10/JITEv10p271-293Rambe981.pdf

Ridgway, S. (2010). Profiles of success: Mark Zuckerberg, creator of Facebook. [viewed 20 July 2010] http:/ / www.workingworld.com/articles / Mark-Zuckerberg-Creator-of-Facebook

Richardson, T. \& Jensen, O. B. (2003). Linking discourse and space: Towards a cultural sociology of space in analysing spatial policy discourses. Urban Studies, 40(1), 7-22. http: / / dx.doi.org/10.1080/00420980220080131

Roode, D., Speight, H., Pollock, M. \& Webber, R. (2004). It's not the digital divide-It's the sociotechno divide! Proceedings of 12th European Conference on Information Systems (ECIS2004), Turku, Finland. http:/ / aisel.aisnet.org/ ecis2004/112/

Rose, D. (2005). Democratising the classroom: A literacy pedagogy for the new generation. Journal of Education, 37, 131-167.

http:/ / dbnweb2.ukzn.ac.za/joe/JoEPDFs/ joe\%2037\%20rose.pdf

Salmon, G. (2000). E-moderating: The key to teaching and learning online. Kogan Page.

Shih, R. C. (2011). Can Web 2.0 technology assist college students in learning English writing? Integrating Facebook and peer assessment with blended learning. Australasian Journal of Educational Technology, 27(Special issue, 5), 829-845. http: / / www.ascilite.org.au/ajet/ajet27/shih.html

Shim, J. P. (2008). Social networking sites: A brief comparison of usage in the U.S. and Korea. Decision Line, October 2008, 16-18. http: / / www.decisionsciences.org/decisionline/Vol39/39_5/ dsi-dl39_5ecom.pdf

Siemens, G. \& Tittenberger, P. (2008). Handbook of emerging technologies for learning. University of Manitoba.

Siemens, G. (2006). Connectivism: Learning and knowledge today. Global summit 2006: Technology connected futures. [not found 15 Mar 2012]

http: / / admin.edna.edu.au/dspace/ bitstream/2150/34771/1/gs2006_siemens.pdf

Sousa, T. (2011). Merging mobile and social media for a powerful mix. The Media Online, 24 November. http:/ / themediaonline.co.za/2011/11/merging-mobile-and-social-media-for-apowerful-mix/

Thompson, M. P. (2005). ICT, power and developmental discourse: A critical analysis. The Electronic Journal of Information Systems in Developing Countries, 20(4), 1-26. http: / / www.ejisdc.org/ojs2/index.php/ ejisdc/article/viewFile/122/122

Van Dijk, T. A. (2006). Discourse and manipulation. Discourse E Society, 17(3), 359-383. http: / / dx.doi.org/ 10.1177/0957926506060250 
Van Dijk, T. A. (2003). Critical discourse analysis. In D. Schiffrin, D. Tannen \& H. E. Hamilton (Eds.), The Handbook of discourse analysis (Ch. 18). Wiley-Blackwell.

http: / / au.wiley.com/WileyCDA/WileyTitle/productCd-0631205969.html

Van Maanen, J. \& Barley, S. (1985). Cultural organisation: Fragments of a theory. In P. Frost, L. Moore, M. Louis, C. Lundberg, \& J. Martin (Eds), Organisational culture (pp 31-54). Sage.

Valenzuela, S., Park, N. \& Kee, K. F. (2008). Lessons from Facebook: The effect of social network sites on college students' social capital. Submitted to the 9th International Symposium on Online Journalism, Austin, Texas, April 4-5, 2008.

http: / / online.journalism.utexas.edu/2008/papers/Valenzuela.pdf

Wodak, R. (1987). And where is the Lebanon? A socio-psycholinguistic investigation of comprehension and intelligibility of news. Text - Interdisciplinary Journal for the Study of Discourse, 7(4), 377-410.

Author: Patient Rambe PhD (UCT), Postdoctoral Research Fellow

Department of Computer Science and Informatics, University of the Free State

205 Nelson Mandela Drive / Rylaan, Park West, Bloemfontein 9301, South Africa

Email: RambeP@ufs.ac.za, pjoerambe@gmail.com

Please cite as: Rambe, P. (2012). Critical discourse analysis of collaborative

engagement in Facebook postings. Australasian Journal of Educational Technology, 28(2),

295-314. http: / / www.ascilite.org.au/ajet/ajet28 / rambe.html 